\title{
RISK MANAGEMENT ON THE WARSHIP TASK OPERATIONS
}

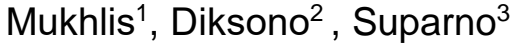 \\ Sekolah Tinggi Teknologi Angkata Laut, \\ STTAL-Bumimoro-Morokrembangan, Surabaya 60187, Indonesia \\ Email:sonodik@gmail.com \\ Orchid id 0000-0002-1492-1025
}

\begin{abstract}
The main task of the Indonesia Navy is to enforce the law and maintain security in the territorial sea of national jurisdiction, so that the Indonesian Navy is required to have the main tool of weapons systems (Alutsista) are always ready to carry out the task. The frequent occurrence of accidents experienced by the Indonesian Warship (KRI). This reduces the ability of Warship in performing the task. The purpose of this research is to investigate the causes and effects of accidents, and seek risk mitigation that is considered appropriate. Formal Safety Assessment (FSA) is a structured and systematic methodology used for maritime safety analysis. The fault tree analysis is used to investigate the cause of marine accidents and the event tree analysis is used to determine the impact of an accident. The results of this study are FSA can be effectively applied in accident investigations, although the calculation of cost benefit analysis for warships can be ignored because the Warship task cannot be compared to the value of money.
\end{abstract}

Keywords: Task Operation, Warship, FSA, fault tree analysis, event tree analysis

\section{INTRODUCTION.}

Indonesia is an archipelagic country with the area of the total national jurisdiction $\pm 8,308$ million $\mathrm{km}^{2}$ (Pushidrosal, 2017). The extent of Indonesia's territorial waters has potential threats to ideology, politics, economics, social culture, defense and security. To deal with these threats, adequate defense capabilities is needed. The unity and integrity of the Unitary Republic of Indonesia are a fixed price that must be championed and defended. Faced with this responsibility, the Indonesian Navy as an element of the TNI (Indonesian national army) force responsible for NKRI's (The Unitary State of the Republic of Indonesia) defense operations at sea, is required to be able to carry out tasks through fostering strength with emphasis on power structures through the SSAT (Putra, et al., 2017).
Warships as one of the main elements of the SSAT are required to have an adequate combat readiness to counter every threat. It is necessary to maintain and improve the condition of warships, so that they are always ready to carry out operations. A marine security patrol was carried out by presenting Warship in all Indonesian waters, including on remote islands. The aim is to carry out routine patrols in the context of enforcing maritime security and maintaining territory from foreign parties (Marsetio, 2014).

Safety and health personnel and material work is an important thing that is always considered in the line of duty regional security. An accident is one of the things that need to be avoided because they cause various losses to the organization. Marine accidents have a negative impact on humans, the environment, activities on board and 
land in a wide variety of forms and levels, and the effects vary from minor injuries to fatalities and environmental damage and mild to severe property (Mullai \& Paulsson, 2011)

We know many accidents that befall Warship. The condition of being trigger reasons the capabilities of crew members of a vessel which is very limited, the condition of Warship having the age of 40 years, a limited number of maintenance and so on. Many fleets of ships are made of fiber, which in terms of specifications are not in accordance with military standards, and the amount that does not meet the demands of the ship's need to carry out operations. Sources of risk to the marine system include equipment failure, external events, human error, and institutional errors (Ayyub, et al., 2002).

Risk management learns how to identify, analyze, evaluate, treat and monitor hazards in Warship operations. Risk management aims to minimize losses that must be borne by an organization (Australian/New Zeland Standart, 2004). Currently it can be developed and proposed for further research, including further detailed risk analysis and analysis of costs and benefits (Mullai \& Paulsson, 2011). The ability to define what might happen in the future, assess the risks and uncertainties associated with and choose between alternative, alternatives lies in the core of the risk management system (Kishore, 2013). The risk management process based on Figure 1.

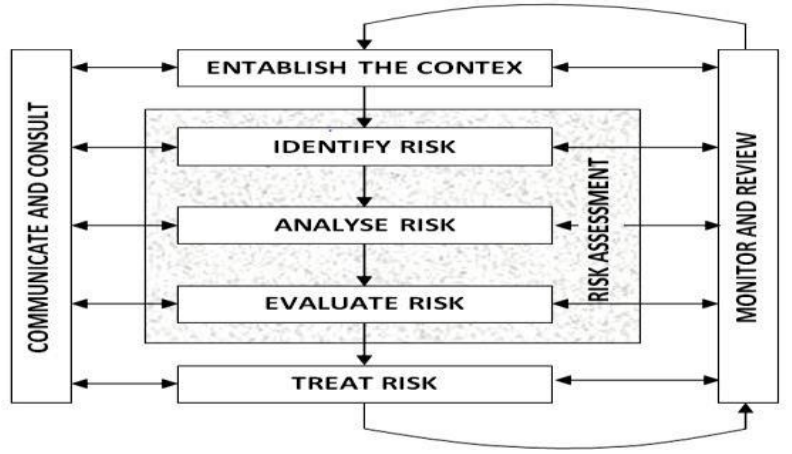

Fig. 1 Risk management process

(Australian/New Zeland Standart, 2004)
Based on several international and national rules, warships are classified as non-conventional vessels or special ships. The rule is that warships are not bound by rules such as the rules as previously mentioned. In carrying out sailing and operating activities, Warship requires rules that must be made not lower than the rules of international conventions. The lack of specific rules that apply to Warship's operating activities cause system management weaknesses, especially those that regulate risk management related to safety and health for personnel and material. Adoption of risk management throughout the ship life cycle, design and operation can provide best practices to reduce risk (Gasparotti \& Rusu, 2012). To maximize marine safety, risks need to be modeled and safety-based decisions must be made in a logical manner (Wang, 2002).

The main problem is how to manage the risks that occur in the implementation of Warship tasks. The purpose of this study is how to use the FSA model to identify, analyze and assess risks that can occur when Warship carries out its operations and then develops risk mitigation scenarios in an effort to reduce risk.

The international shipping industry has adopted a proactive approach to establishing safety rules through Formal Safety Assessment (FSA). The FSA was introduced by IMO as a structured and systematic methodology that was used for maritime safety analysis and to formulate safety related policies The FSA was introduced by IMO as a structured and systematic methodology that was used for maritime safety analysis and to formulate safety related policies. Shinoda and Tamura reported that the FSA was an effective methodology developed and applied to investigate ship accidents (Shinoda \& Tamura, 2012). The FSA aims to improve maritime safety, including protection of marine life, health, environment and property, using risk analysis and assessing costs and benefits as 
well as several risk control options (International Maritime Organization, 2002). FSA can be used as a tool to evaluate new safety regulations or make comparisons between regulations to be improved (DNV, 2002). The FSA consists of the following steps:

a. Hazards identification.

b. Risk analysis.

c. Risk control options.

d. Cost benefit assessment.

e. Recommendations for decisionmaking.

The analysis phase uses the fault Tree Analysis (FTA) and Event Tree Analysis (ETA) models. Fault Tree Analysis is a technique used to identify risks that contribute to failure or accident (Mullai, 2006). FTA is the easiest method to understand in finding the core of the problem (Soares, 2012). Event Tree Analysis is a logic diagram used to analyze the effects of accidents, failures or unwanted events (Mullai, 2006). In principle FTA and ETA techniques are the most suitable principles for applications in risk analysis in marine transportation (Mullai \& Paulsson, 2011).

\section{MATERIAL/METHODOLOGY}

Scientific research requires a systematic framework in order to ease the course of the research. The research framework must be structured according to the issues reviewed. For more detail research methodology displayed in Figure 2.

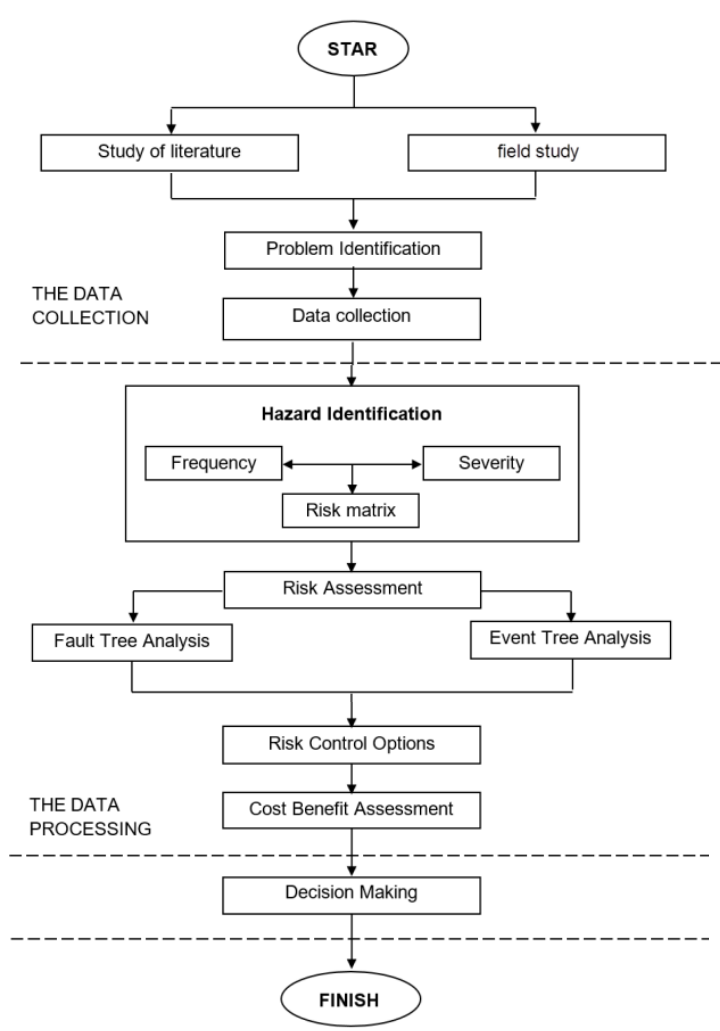

Fig. 2 Stock Flow

On stage data collection, the data collected in the form of qualitative. The qualitative method is a better choice at early stages of study (Jieying, 2013). The data of accidents were collected from the records of the operations staff, previous research and various kinds of media that were considered to support the research. The preliminary data is the data of accident events experienced by Warship as a problem as illustrated in Table 1. Furthermore, the data are processed and combined with supporting data obtained through the assessment of experts. The experts are personnel who are considered competent in that section.

Table 1. Warship accident data

\begin{tabular}{|c|c|c|c|c|c|c|c|c|c|c|c|c|}
\hline \multirow{2}{*}{ TPES } & \multicolumn{10}{|c|}{ YEAR } & \multirow{2}{*}{\multicolumn{2}{|c|}{ AllOWT }} \\
\hline & 181716 & 615 & 141 & 1312 & & 0918 & 0706 & 155 & 4030 & 2201 & & \\
\hline 1 Shipowlisonbystip & 1 & & & & & 1 & & & & 2 & & 4 \\
\hline 2 Shipowlison with a whar & & 1 & & & & & & & & | & & 1 \\
\hline 3 Crashing a tlatingobied & 32 & & & & & & & 1 & & & & 9 \\
\hline 4 Aground & 11 & & & & & & & 1 & & 2 & & 6 \\
\hline 5 Leakgye & 122 & & & & 1 & & & & & 1 & & 8 \\
\hline 6 Sink & 11 & & & 1 & 1 & 11 & & & & 1 & 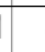 & 8 \\
\hline 7 Fre & 22 & & & 1 & & 1 & & & & & & 6 \\
\hline 8 Human hecident & & & 1 & 1 & & & & & & & & 2 \\
\hline
\end{tabular}




\section{RESULTS AND DISCUSSION}

In accordance with the FSA procedure, the stages of the steps are carried out:

\section{a. Determination of consequence criteria value}

In this phase identified several species of accident often experienced of them are:

1. Ship collision by ship

2. Ship collision by wharf

3. Crashing a floating object

4. Aground

5. Leakage

6. Sink

7. Fire

8. Human Accident

Of the several types of accidents identified, there are several components that are at risk of receiving the impact of the accident, including Warship, crew, property, environment, and third parties in this case shipping service users. The next step is to determine the consequence criteria based on expert judgment and several standards that have been determined as shown in Table 2 .

Table 2. The criteria for a consequence an accident of Warship

\begin{tabular}{|c|c|c|c|c|c|c|}
\hline Severity & & Warship & Crew & Property & Shipping Users & $\begin{array}{c}\text { Environmen } \\
\text { tal }\end{array}$ \\
\hline Catastrophic & 1 & $\begin{array}{l}\text { Can not re- } \\
\text { implement } \\
\text { regional } \\
\text { security } \\
\text { tasks? }\end{array}$ & $\begin{array}{l}\text { Multiple violent } \\
\text { deaths and / or } \\
\text { widespread } \\
\text { fatal disease }\end{array}$ & Total loss & \begin{tabular}{|l|} 
Disasters (the \\
scope is \\
international, the \\
port is closed, \\
the voyage is \\
disrupted for \\
long periods \\
Serious and \\
happiness for a \\
long time, no \\
trade)
\end{tabular} & $\begin{array}{l}\text { Uncontained } \\
\text { or } \\
\text { Widespread } \\
\text { damage }\end{array}$ \\
\hline $\begin{array}{l}\text { Fatal/ } \\
\text { Critical }\end{array}$ & 2 & $\begin{array}{l}\text { Guard duty } \\
\text { delayed } \\
\text { maximum a } \\
\text { month }\end{array}$ & $\begin{array}{l}\text { Single death } \\
\text { and / or } \\
\text { multiple } \\
\text { severe injuries } \\
\text { or severe } \\
\text { occupational } \\
\text { illness }\end{array}$ & \begin{tabular}{|l|} 
Major \\
system \\
Loss
\end{tabular} & $\begin{array}{l}\text { The national } \\
\text { scope, the port } \\
\text { temporarily } \\
\text { closed from the } \\
\text { cruise for } \\
\text { several days. } \\
\text { Here is no } \\
\text { trading }\end{array}$ & $\begin{array}{l}\text { Major } \\
\text { damage }\end{array}$ \\
\hline $\begin{array}{l}\text { Severe / } \\
\text { Marginal }\end{array}$ & 3 & $\begin{array}{l}\text { Guard duty } \\
\text { delayed } \\
\text { maximum } 7 \\
\text { days }\end{array}$ & $\begin{array}{l}\text { Single severe } \\
\text { injury or } \\
\text { accupational } \\
\text { illness and / or } \\
\text { multiple minor } \\
\text { injuries }\end{array}$ & $\begin{array}{l}\text { Controlled } \\
\text { System } \\
\text { Damage }\end{array}$ & $\begin{array}{l}\text { Stop temporary } \\
\text { shipping or } \\
\text { extension of } \\
\text { shipping } \\
\text { restrictions }\end{array}$ & $\begin{array}{l}\text { Controlled } \\
\text { short- } \\
\text { Term } \\
\text { damage }\end{array}$ \\
\hline $\begin{array}{l}\text { Minor / } \\
\text { Negligible }\end{array}$ & 4 & $\begin{array}{l}\text { Duty of } \\
\text { security got } \\
\text { delayed for } \\
\text { some time }\end{array}$ & $\begin{array}{l}\text { Minor injury / } \\
\text { occupational } \\
\text { IIIness }\end{array}$ & $\begin{array}{l}\text { Minor } \\
\text { damage }\end{array}$ & $\begin{array}{l}\text { Short term } \\
\text { losses }\end{array}$ & $\begin{array}{l}\text { Minor local } \\
\text { damage }\end{array}$ \\
\hline
\end{tabular}

To determine the impact weight borne by the recipient of the risk, an assessment was carried out by experts, the continuation of the data was processed using the Analytical Hierarchy Process (AHP) method, so that the weighting results obtained in accordance with Table 3.

Table 3. The weighting of risk recipients

\begin{tabular}{|c|c|}
\hline Criteria & Weight \\
\hline Warship & 0,458 \\
\hline Crew & 0,285 \\
\hline Property & 0,054 \\
\hline Environment & 0,150 \\
\hline Shipping users & 0,053 \\
\hline
\end{tabular}

\section{Hazards Identification}

At this stage we make a list of all accident scenarios that are relevant to potential causes with values based on the level of risk and its consequences. The method used is creative techniques and analysis that is by expert judgment or literature study. The intended value is the level of risk based on consideration of risk criteria for receiving ALARP according to Figure

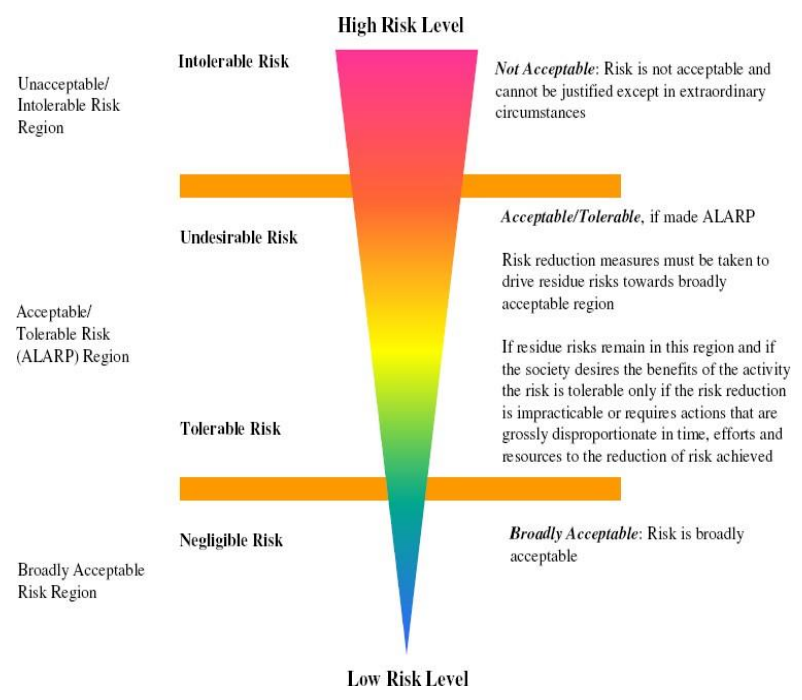

Fig. 3 The framework the reception of the risk and strategies the actions of risk management 
By combining the level of consequence (Table 2) and frequency (Tabel 4) of occurrence, it obtains the severity level matrix. To sort the types of accidents that need to get priority handling, the risk matrix is multiplied by the recipient's risk weight which results in accordance with Table 5.

Table 4. Frequency of hazard (The Royal Institution of Naval Architects, 2010)

\begin{tabular}{|l|c|l|}
\hline \multicolumn{2}{|c|}{ FREQUENCY } & \multicolumn{2}{c|}{ DEFINITION } \\
\hline Frequent & 1 & Continuously occurs \\
\hline Probable & 2 & Likely to occur repeatedly \\
\hline Occasional & 3 & $\begin{array}{l}\text { Likely to occur several times during the } \\
\text { operational life of the system }\end{array}$ \\
\hline Remote & 4 & $\begin{array}{l}\text { Likely to occur at some time in the } \\
\text { system life-cycle }\end{array}$ \\
\hline Improbable & 5 & Unlikely to occur during operational life \\
\hline Incredible & 6 & $\begin{array}{l}\text { Extremely unlikely to occur (but beware } \\
\text { assuming this means never) }\end{array}$ \\
\hline
\end{tabular}

Table 5. The value of severity Warship accident

\begin{tabular}{|c|c|c|c|c|c|c|c|c|c|c|c|c|c|}
\hline \multirow[b]{2}{*}{$\begin{array}{l}\text { के } \\
\text { है } \\
\sum_{z}\end{array}$} & \multirow[b]{2}{*}{ 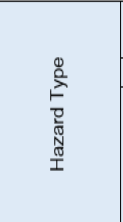 } & \multicolumn{5}{|c|}{$\begin{array}{c}\text { The Biggest Possible Consequences } \\
\text { Hazard Impact Assessment }\end{array}$} & \multicolumn{5}{|c|}{$\begin{array}{l}\text { Possible Consequences } \\
\text { Worst } \\
\text { Hazard Impact Assessment }\end{array}$} & \multirow[b]{2}{*}{$\begin{array}{l}\overrightarrow{\mathrm{c}} \\
\overrightarrow{\mathrm{g}} \\
\overrightarrow{\mathrm{\xi}}\end{array}$} & \multirow[b]{2}{*}{$\begin{array}{l}\text { 姜 } \\
\text { ष्ञ }\end{array}$} \\
\hline & & $\overline{\underline{q}}$ & 总 & $\begin{array}{l}\frac{\overrightarrow{1}}{0} \\
\frac{0}{2} \\
\frac{0}{2}\end{array}$ & 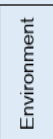 & 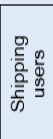 & $\overline{\underline{\alpha}}$ & 胥 & $\begin{array}{l}\frac{2}{0} \\
\frac{0}{2} \\
\frac{2}{2} \\
0\end{array}$ & 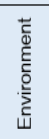 & 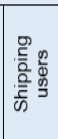 & & \\
\hline 1 & $\begin{array}{l}\text { Ship collision by } \\
\text { ship }\end{array}$ & 2,747 & 1,426 & 0,272 & 0,750 & 0,263 & 2,747 & 1,426 & 0,326 & 0,600 & 0,316 & 10,873 & 5 \\
\hline 2 & $\begin{array}{l}\text { Ship collision } \\
\text { with a wharf }\end{array}$ & 1,831 & 1,141 & 0,218 & 0,600 & 0,211 & 2,747 & 1,426 & 0,326 & 0,750 & 0,316 & 9,565 & 8 \\
\hline 3 & $\begin{array}{l}\text { Crashing a } \\
\text { floating object }\end{array}$ & 2,289 & 1,426 & 0,272 & 0,750 & 0,263 & 2,747 & 1,426 & 0,326 & 0,750 & 0,263 & 10,512 & 6 \\
\hline 4 & Aground & 2,747 & 1,712 & 0,381 & 0,900 & 0,316 & 2,747 & 1,426 & 0,381 & 0,900 & 0,316 & 11,824 & 4 \\
\hline 5 & Leakage & 3,204 & 1,712 & 0,326 & 0,900 & 0,316 & 4,120 & 1,997 & 0,435 & 1,050 & 0,316 & 14,375 & 3 \\
\hline 6 & Sink & 4,120 & 1,997 & 0,490 & 1,050 & 0,368 & 4,120 & 2,282 & 0,490 & 1,199 & 0,421 & 16,536 & 1 \\
\hline 7 & Fire & 3,662 & 1,997 & 0,435 & 0,900 & 0,368 & 3,662 & 1,997 & 0,435 & 0,900 & 0,368 & 14,724 & 2 \\
\hline 8 & Human Accident & 1,831 & 1,712 & 0,218 & 0,600 & 0,211 & 2,747 & 1,997 & 0,218 & 0,600 & 0,211 & 10,342 & 7 \\
\hline
\end{tabular}

Based on these calculations five types of accidents are taken that have a high risk that requires risk mitigation measures. The five types of accidents are:
1. Sink
2. Fire
3. Leakage
4. Aground
5. A collision with a ship

\section{b. Risk Analysis}

The purpose of this risk analysis is to investigate in detail the causes and consequences of the scenarios identified in the hazard identification step. This analysis is focused on high- risk areas.

1. Fault tree analysis

Fault tree analysis is used to determine the common causes of accidents that experienced Warship. Various causes of accidents can be seen in Figure 4 to Figure 8

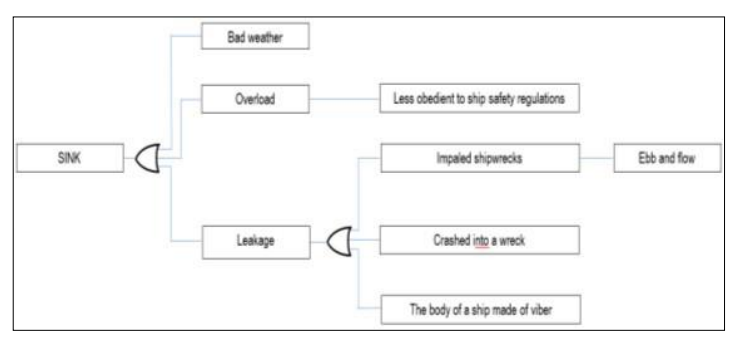

Fig. 4 Fault tree analysis sinks

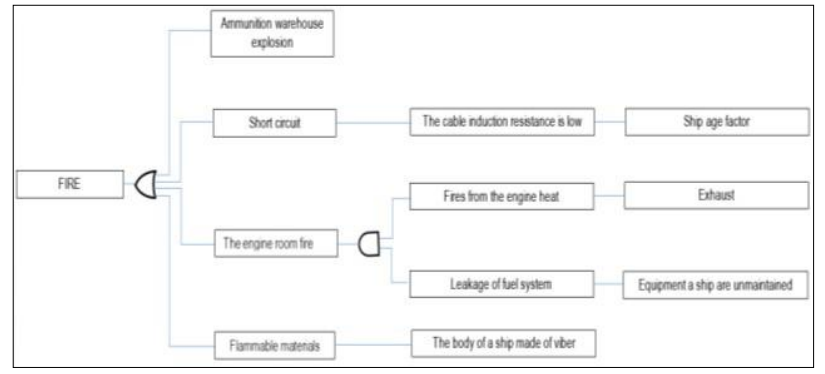

Fig. 5 Fault tree analysis fire

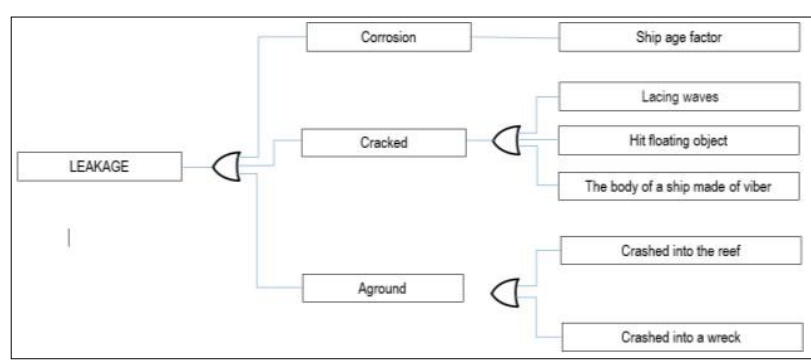

Fig. 6 Fault tree analysis leakage

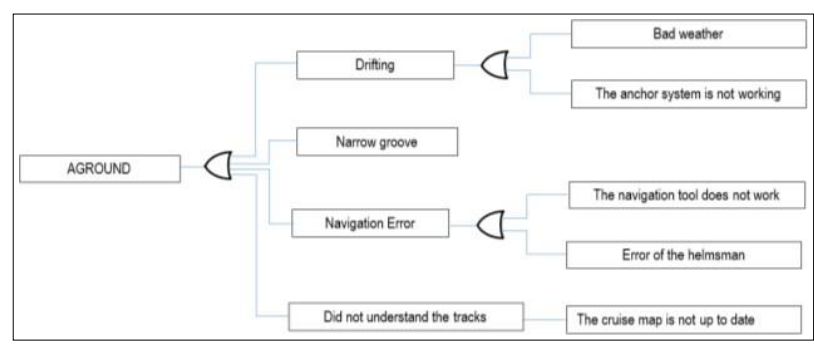

Fig. 7 Fault tree analysis aground 


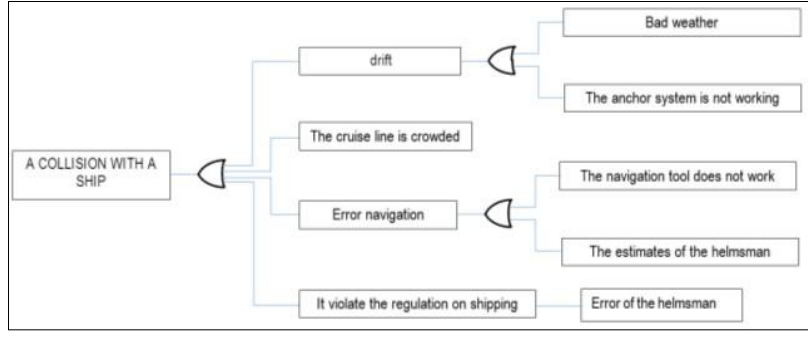

Fig. 8 Fault tree analysis a collision with a ship

1. Event tree analysis

Event tree analysis is used to determine the impact of the accident experienced by Warship. Various impacts of accidents can be seen in Figure 9 to Figure 13.

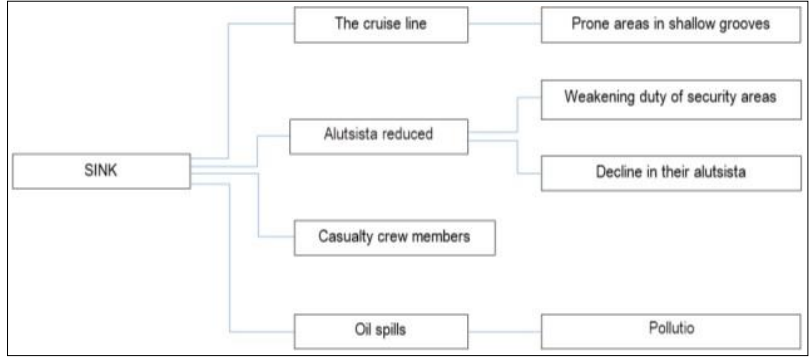

Fig. 9 Event tree analysis sinks

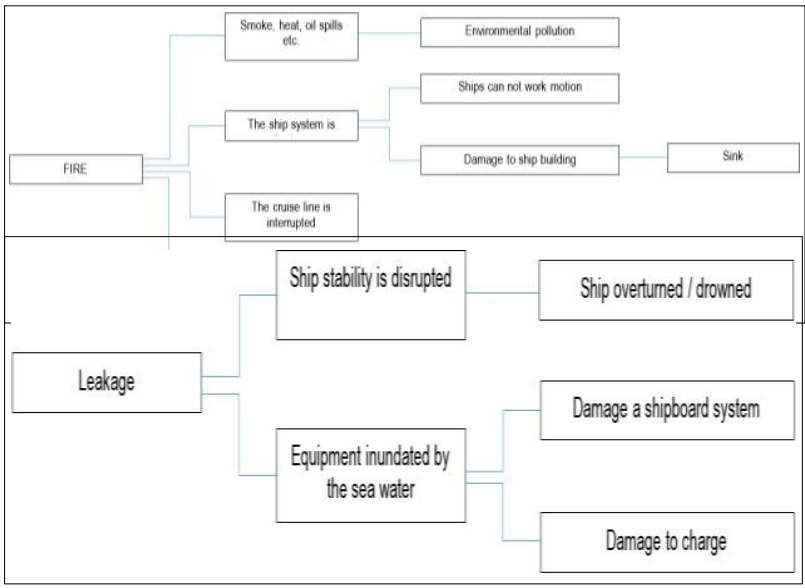

Fig. 11 Event tree analysis leakage

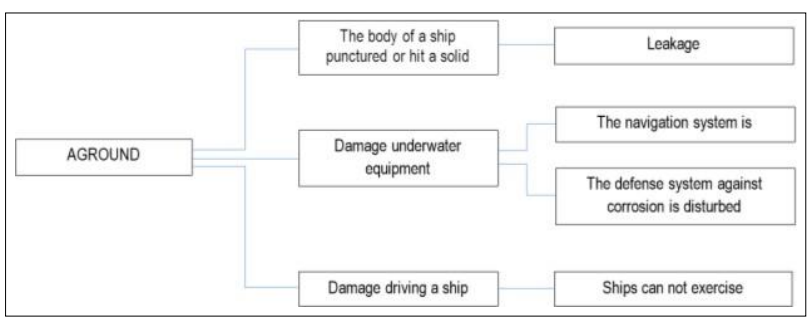

Fig. 12 Event tree analysis aground

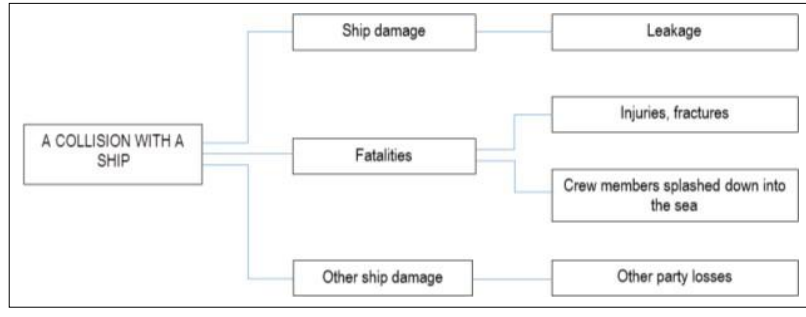

Fig. 13 Event tree analysis a collision with a ship

\section{c. Risk Control Options}

The aim of the RCO step is to propose effective and practical risk control options. There are several steps could be done to reduce the risk of:

1. Seaman training and certification (PSP)

2. Ship rescue training (PPK)

3. Human rescue training (PPM)

4. Improved quality control and periodic inspections (PMI)

5. Preparation of ship maintenance schedule (PJP)

6. Fulfillment of personnel according to DSP (PJM)

7. The purification of the reporting system (PSL)

\section{d. Cost Benefit Assessment}

In principle, the calculation of costs carried out follows the equation widely used in FSA applications called Gross Cost of Averting a Fatality (GCAF) expressed in the form (Kontovas \& Psaraftis, 2009):

$\mathrm{GCAF}=\frac{\Delta \mathrm{C}}{\Delta \mathrm{R}}$

$\Delta \mathrm{C}:$ Cost of risk control

$\Delta R$ : Risk reduction after risk control

For the calculation of the estimated cost of activities is only activities that can be calculated mathematically, while for activities that are task routines are not calculated. 
Table 6. Cost and risk reduction calculation tables

\begin{tabular}{|c|c|c|c|c|}
\hline & Risk Control Option & Cost & Risk Reduction & Description \\
\hline 1 & $\begin{array}{l}\text { Seaman training and } \\
\text { certification (PSP) }\end{array}$ & 438.660 .000 ; & $27,09 \%$ & \\
\hline 2 & Ship rescue training (PPK) & 383.700 .000 & $30,84 \%$ & \\
\hline 3 & Human rescue training (PPM) & 203.420.000; & $5,16 \%$ & \\
\hline 4 & $\begin{array}{l}\text { Improved quality control and } \\
\text { periodic inspections (PMII) }\end{array}$ & & $18,50 \%$ & $\begin{array}{l}\text { Follow-up } \\
\text { maintenance system }\end{array}$ \\
\hline 5 & $\begin{array}{l}\text { Preparation of ship } \\
\text { maintenance schedule (PJP) }\end{array}$ & & $30,84 \%$ & $\begin{array}{l}\text { Customized to the } \\
\text { budget }\end{array}$ \\
\hline 6 & $\begin{array}{l}\text { Fulfillment of personnel } \\
\text { according to DSP (PJM) }\end{array}$ & & $12,34 \%$ & $\begin{array}{l}\text { DSP is a list of } \\
\text { personnel } \\
\text { arrangements } \\
\end{array}$ \\
\hline 7 & $\begin{array}{l}\text { The purfication of the } \\
\text { reporting system (PSL) }\end{array}$ & 10.192.000.000, & $21,59 \%$ & \\
\hline
\end{tabular}

To choose the best of several types of risk reduction efforts that exist as in Table 4, we can choose by looking at which types of countermeasures have the lowest ICAR index. This is based on the smaller the ICAR value, the better the effectiveness of risk mitigation carried out on risk reduction.

\section{e. Recommendations for decision-making}

Actions to reduce the risk of accidents experienced by Warship can be recommended to decision makers as follows:

1. Ship rescue training (PPK) with the ICAR index RP. 12.441.634,-

2. Seaman training and certification (PSP) with the ICAR index RP. 16.192.691,03

3. Being something that needs to be understood, that the measure of 5 . regional security is an absolute thing that cannot be measured by nominal money. Even though it is calculated as economically detrimental, but in terms of benefits it is considered very large, it can be a decision that is considered appropriate.

\section{CONCLUSION.}

From the results of the analysis, the following conclusions were obtained:

a. The Hazard Identification process produces eight types of accidents that often occur when Warship performs operations. The eight types of accidents, there are five types of accidents that have the highest risk that is:

1. Sink

2. Fire

3. Leakage

4. Aground

5. Collision with a ship

b. Each accident is caused by several factors reflected in a fault tree analysis that is largely due to human error. While the impact of the top event is reflected in the event tree analysis. The main impact that must be borne is the ability of Warship operations to be reduced, so that the task of safeguarding the territorial waters becomes less optimal.

The FSA is a structured and effective methodology in managing shipping risk management, including for warships, although in calculating the cost and benefit assessment in the military field can be ignored. This is because the task of securing territorial waters cannot be assessed with money.

\section{REFERENCES}

Australian/New Zeland Standart, 2004. Risk Management AS/NZS 4360:2004. s.I.s.n.

Ayyub, B. M., Beach, J. E., Sarkani, S. \& Assakkaf, I. A., 2002. Risk Analysis and Management for Marine Systems. Naval Engineers Journal, p. 181206.

DNV, 2002. Formal Safety Assessment - Large Passengger, s.l.: s.n. 
Gasparotti, C. \& Rusu, E., 2012. Mhetods for The Risk Assessment in Maritime Transportation in The Black Sea Basin. Journal of Environmental Protection and Ecology, pp. 1751-1759.

International Maritime Organization, 2002. Guidelines for Formal Safety Assessment (FSA) for Use in The IMO Rule-Making Process. London: s.n.

Jieying, X., 2013. Study on the implementation of formal safety assessment for the development of the mandatory polar code, Malmö: World Maritime University.

Kishore, E. A., 2013. Formal Safety Assessment in Maritime Industry-Explanation to IMO Guidelines. [Online] Available at: www.researchgate.net [Diakses 14 Januari 2018].

Kontovas, C. A. \& Psaraftis, H. N., 2009. Formal Safety Assessment: A Critical Review. Marine Technology, p. 45-59.

Marsetio, 2014. Sea Power Indonesia. Jakarta: Universitas Pertahanan.

Mullai, A., 2006. Risk Management System - Risk Assessment Framework and Techniques. 5 penyunt. Turku: Dagob.

Mullai, A. \& Paulsson, U., 2011. A grounded theory model for analysis of marine accidents. Accident Analysis and Prevention, Volume 43, p. 1590-1603.

Pushidrosal, 2017. Data of the Territory of the Unitary State of the Republic of Indonesia, Jakarta: Pushidrosal.

Putra, I. N., Hakim, A., Pramono, S. H. \& Tolle, H., 2017. Adobted COBIT-5 Framework for System
Design of Indonesia Navy IS/IT: An Evaluation. International Journal of Applied Engineering Research, 12(17), pp. 6420-6427.

Shinoda, T. \& Tamura, Y., 2012. Development of Risk Assessment Based on FSA ang ITS Aplication Collision Between Fishing Vessels and Cargo Vessels. Seminar Nasional Teori dan Aplikasi Teknologi Kelautan, pp. 19-25.

Soares, A. P. T. a. C. G., 2012. Fault Tree AnalysisFault Tree Analysis, s.l.: Instituto Superior Techino.

Wang, J., 2002. Offshore safety case approach and formal safety assessment of ships. Journal of Safety Research, Volume 33, p. $81-115$. 